\title{
Learners between Childhood and Adulthood: Assessing Writing Competences of Teens Learning French as a Foreign Language
}

Meta LAH ${ }^{1}$

$\approx$ The article introduces learners between two age groups: childhood and adulthood. The aim of the author is to analyse the writing skills of French primary school learners - mostly 14 years old - and to determine which descriptors could be used to assess them. The article begins with a presentation of the learners' characteristics and continues with a review of the position of the French language in Slovenian primary schools, where French is taught as a second foreign language and an elective subject. Since French is a rather infrequent subject in primary schools, it is difficult to obtain comparable materials. Finally, 36 written compositions from the national French competition serve as the basis for analysis. The detailed analysis is accompanied by a presentation of the CEFR and AYLLIT descriptors for writing, as well as reflection on which descriptors are appropriate for assessing compositions and placing them on the CEFR levels. The AYLLIT descriptors seem more relevant, as they are more explicit and appropriate for the target group.

Keywords: French as a foreign language, learners between two age groups, second foreign language, national competition, written compositions, CEFR descriptors, AYLLIT descriptors 


\section{Učenci med otroštvom in odraslostjo: ocenjevanje pisnih zmožnosti najstnikov, ki se učijo francoščine kot tujega jezika}

Meta LaH

$\approx$ V prispevku so predstavljeni učenci, ki sodijo v dve starostni skupi$\mathrm{ni}$ - med otroštvo in odraslost. Avtorica v prispevku analizira pisne zmožnosti osnovnošolskih učencev, ki se učijo francoščino (večinoma so stari 14 let), in prepoznava opisnike, ki bi jih lahko uporabili pri ocenjevanju. V prispevku so na začetku predstavljene značilnosti učencev, $\mathrm{v}$ nadaljevanju pa pregled položaja francoskega jezika $\mathrm{v}$ slovenskih osnovnih šolah. Francoščina se poučuje kot drugi/tuji jezik in izbirni predmet. Ker je to sorazmerno redek predmet v osnovnih šolah, je težko pridobiti primerjalno gradivo. Tako je bilo na koncu za analizo uporabljenih 36 pisnih izdelkov iz državnega tekmovanja iz francoščine. Poleg podrobne analize so predstavljeni opisniki za pisanje Skupnega evropskega jezikovnega okvira (SEJO) in AYLLIT. Avtorica skuša ugotoviti, kateri od obeh opisnikov so primernejši za ocenjevanje analiziranih izdelkov in njihovo umeščanje v SEJO. Zdi se, da so opisniki AYLLIT ustreznejši, saj so jasnejši in primernejši za to starostno skupino.

Ključne besede: francoščina kot tuji jezik, učenci med dvema starostnima skupinama, drugi tuji jezik, državno tekmovanje, pisni izdelki, opisniki SEJO, opisniki AYLLIT 


\section{Introduction}

The topic of teaching a foreign language to young learners was neglected for a long time, especially regarding the field of assessing knowledge for this age group, with thorough research only beginning after 1990 (Sundquist, 2014, p. 1). The Common European Framework for Languages brought many innovations to the field of testing and assessing young learners' knowledge, but it was nevertheless "based on extensive and thorough research of how adults go about acquiring another language and why" (Sešek \& Pižorn, 2009, p. 294). Pižorn adds that "there are features that may be important for a particular context, but which are not addressed by the CEFR" (2014, p. 244).

Children start learning foreign languages increasingly early. As Moon and Enever stress, the term "young learner" is potentially misleading, as it is used for all children from birth ${ }^{2}$ - or sometimes even prenatally - until the age of 18 years (2010, p. 2). The expression "young learner" is therefore perceived as questionable; if children can begin the process of learning a foreign language immediately after birth, it is difficult to define when they are no longer "young learners". There are various interpretations of the term, but legally speaking "young learners" are learners aged 18 or less who are still under parental care (Ellis, 2014, p. 75). Ellis also quotes the owner of a Paris language school, who defines a "young learner" as either someone who has just started learning English or as a five-year-old child (Ellis, 2014, p. 75). The fact that primary school systems vary from country to country should also be taken into consideration. Children do not have equal opportunities to learn a foreign language; in some countries, children attend primary school from age 5 to 11, whereas in other countries they enter education later, when they are 6 or 7 , and they finish when they are 14 (Pinter, 2006, p. XIII). The latter is the case in Slovenia.

The present research focuses on adolescents learning French as a second foreign language. The pupils who participated in the study were in the final (ninth) year of primary school and were typically 14 years old. They were attending French lessons voluntarily for two hours per week, and in most cases were in their third year of learning French. The specifics of French in primary schools will be presented later.

Following a presentation of learners between the two age groups and the situation regarding teaching French in primary schools in Slovenia, the article focuses on a detailed content analysis of comparable written assignments produced by the same learners. CEFR and AYLLIT descriptors for writing are

2 Marjanovič Umek quotes studies stating that anything from 3 or 4 to 7 or 8 is regarded as a suitable age to begin learning a foreign language (2009, p. 75). 
also presented, as the research attempts to establish which descriptors are more appropriate for describing the analysed assignments.

\section{Learners between two age groups}

According to some authors (Aitchison, 1997; Rixon, 1999, in Ellis, 2014, p. 76), one can no longer be considered a young learner after reaching puberty (at the age of 12 or 13). This age limit has been chosen for many reasons: it is a time of rapid mental and physical development, social habits and behaviours change, and it is the age when pupils in many countries need to enrol in secondary education for the first time. Ellis quotes various studies from the field of language learning and acquisition, based on which it is safe to assume that it is exactly around this age that considerable changes occur in the process of learning foreign languages. For younger children, learning a foreign language resembles learning the mother tongue (Ellis, 2014, p. 76). Marjanovič Umek (2009, p. 75) emphasises that learning a language before puberty is not only linked to the biological and neurological characteristics of the learner, but also and primarily to social factors.

Several authors distinguish between "young" and "older" children. According to Gaonac'h (2006, p. 20), different studies accept the statement that between the age of seven and puberty there is a significant drop in the capacity to acquire language competence similar to the competence of a native speaker. Newport (1999, p. 12) adds "For example, in much of developmental psychology, insofar as there are maturational effects, an uncontroversial generalization is typically that big kids are better than little kids. In language acquisition (and possibly in other domains as well), however, the child, and not the adult, appears to be especially privileged as a learner". Authors also stress that the advantages of young learners are better outputs in the domain of listening comprehension and speaking, and especially in the domain of better pronunciation (Lah Šuster, 2013, p. 96; Gaonac'h, 2006, p. 20).

The difference between young children and teens also consists in the way they learn and the way they are taught. Younger children are usually taught through language immersion, which Brumen says can be used in a "hard" or "soft" way (the "soft" way meaning cross-curricular teaching) (Brumen, 2003; Lah Šuster, 2013).

On the other hand, older children are more capable of analysing and collecting information, as well as organising their thoughts. They are supposed to acquire morphological and syntactic structures more rapidly (Lah Šuster, 2013), which is quite logical in view of their cognitive and mental development. 
The learners involved in the present study are, however, in a different position than young learners due to another factor: French is their second foreign language and (like adult learners - Oh, 2011, p. 55) their literacy is more developed. They can transfer learning strategies from one foreign language to another. They also learn French "as a subject" (Hasselgreen et al., 2011), not by immersion, just as they learn any other subject in their curriculum.

They nevertheless possess several qualities of "young learners". From teachers' reports - and from presentations, such as their performances at the Journée francophone - it is evident that these pupils approach foreign language learning with enthusiasm and an open mind, which is a typical characteristic of children (Drew \& Hasselgreen, 2008, p. 1). Furthermore, they started to learn French quite recently, which could be one of the criteria for labelling them "young learners".

\section{The position of French in the Slovenian school system}

In order to justify the choice and size of the corpus, let us first introduce the position of French in the Slovenian school system. In Slovenian primary schools, French is taught as a second foreign language and in most cases is not compulsory. The number of pupils learning French is significantly lower than the number of pupils learning German, a language that is much more present in the Slovenian education system. According to data of the Statistical Office of the Republic of Slovenia, there were 1,738 pupils learning French in 2010; it was a compulsory subject for only 89 pupils, whereas 1,345 took it as an optional subject and 349 as an extra-curricular activity. In the same year, 24,057 primary school pupils were learning German as a second foreign language. In 2013/14, there were 1,519 pupils learning French as an optional second foreign language in primary schools. ${ }^{3}$

The situation has changed in the past five years, as a second foreign language can no longer be taught as a compulsory subject in primary schools, while the age limit for choosing a foreign language as an elective subject has been lowered. At present, pupils can choose a second foreign language as early in the $4^{\text {th }}$ year of primary school. The present article does not intend to discuss the potential benefits of early foreign language learning, as opinions on this topic vary (Drew \& Hasselgreen, 2008; Gaonac'h, 2006; Copland \& Garton, 2014; Moon \& Enever, 2010); nevertheless, it is possible to agree to some extent with Dagarin, who says, "the current state of affairs in Slovenia is rather chaotic, since early

3 http://www.stat.si/StatWeb/glavnanavigacija/podatki/prikazistaronovico? IdNovice $=3858$, National Education Institute of the Republic of Slovenia. 
language learning occurs in various forms and at different levels" (2009, p. 156). It is essential that a good system for second foreign language learning is constructed to enable children to learn a second foreign language for three to six years. When entering and exiting the learning process, the second foreign language often remains on the level of awakening to language.

\section{Methodology}

Second foreign language evaluation and grading is poorly researched in Slovenia. Some studies have been carried out on assessment of the first foreign language (e.g., Brumen, Čagran, \& Rixon, 2005), but little is known about how teachers assess knowledge of a second foreign language, which is mostly learned by teens.

For the purposes of the present paper, the last part of written assignments from a national French competition for primary school pupils will be analysed. The tasks in the first part offer a relatively small amount of information regarding language knowledge, and some of the tasks (true/false, matching) also enable guessing. Written compositions, on the other hand, lead to the assessment of various aspects: following the rules of the text type, following instructions, and using appropriate content and language knowledge. Similar to the AYLLIT project (Hasselgreen et al., 2011, pp. 18-19), pupils are expected to be able to write a short text on a predefined topic, following all of the requirements given in the instructions.

The methodology of the research includes the following steps:

- $\quad$ a detailed analysis of the compositions, using predefined criteria;

- $\quad$ an analysis of CEFR and AYLLIT descriptors for writing;

- consideration of the suitability of the descriptors for assessing the analysed written compositions.

Before analysing the assignments, it was assumed that participants would be able to meet the formal criteria, i.e., to write the required number of words and respect the form of a letter. It was also assumed that they would use basic vocabulary and simple structures without making mistakes that would affect comprehension.

The CEFR and AYLLIT descriptors that were taken into account were those for levels A1 to B1. According to Hasselgreen et al. (2011, p. 11), "levels beyond $\mathrm{B}_{1}$ are beyond the cognitive reach of children". Our learners are between two age groups, but we assume their language level not to be above B1 due to the number of hours of learning French as a foreign language. 
The descriptors are as follows:

CEFR criteria (2001):

Self-assessment grid (pp. 26-27)

\begin{tabular}{|l|l|l|}
\hline A1 & A2 & B1 \\
\hline $\begin{array}{l}\text { I can write a short postcard } \\
\text { which for example, sending } \\
\text { holiday greetings. I can fill in } \\
\text { forms with personal details } \\
\text { which for example, entering } \\
\text { my name, nationality and }\end{array}$ & $\begin{array}{l}\text { I can write short, simple notes } \\
\text { and messages relating to } \\
\text { matters in areas of immedi- } \\
\text { address on a hotel registra- } \\
\text { tion form. }\end{array}$ & $\begin{array}{l}\text { I can write a simple connected } \\
\text { simpersonal letter, for } \\
\text { example, thanking someone } \\
\text { or of personal interest. I } \\
\text { can write personal letters } \\
\text { describing experiences and } \\
\text { impressions. }\end{array}$ \\
\hline
\end{tabular}

\section{Overall written production (p. 61)}

\begin{tabular}{|l|l|}
\hline B1 & $\begin{array}{l}\text { Can write straightforward connected texts on a range of familiar subjects within his/her } \\
\text { field of interest, by linking a series of shorter discrete elements into a linear sequence. }\end{array}$ \\
\hline A2 & $\begin{array}{l}\text { Can write a series of simple phrases and sentences linked with simple connectors like } \\
\text { 'and', 'but' and 'because'. }\end{array}$ \\
\hline A1 & Can write simple isolated phrases and sentences. \\
\hline
\end{tabular}

\section{Correspondence (p. 83)}

\begin{tabular}{|l|l|}
\hline B1 & $\begin{array}{l}\text { Can write personal letters giving news and expressing thoughts about abstract or cultural } \\
\text { topics, such as music, films. }\end{array}$ \\
\cline { 2 - 3 } & Can write personal letters describing experiences, feelings and events in some detail. \\
\hline A2 & Can write very simple personal letters expressing thanks and apology. \\
\hline A1 & Can write a short simple postcard. \\
\hline
\end{tabular}

The AYLLIT criteria (Hasselgreen et al., 2011, pp. 23-24)

\begin{tabular}{|c|c|c|c|c|}
\hline & $\begin{array}{l}\text { Overall structure and } \\
\text { range of information }\end{array}$ & $\begin{array}{l}\text { Sentence structure } \\
\text { and grammatical } \\
\text { accuracy }\end{array}$ & $\begin{array}{l}\text { Vocabulary and } \\
\text { choice of phrase }\end{array}$ & $\begin{array}{l}\text { Misformed } \\
\text { words and } \\
\text { punctuation }\end{array}$ \\
\hline $\mathrm{A} 2 / \mathrm{B} 1$ & $\begin{array}{l}\text { Is able to make reason- } \\
\text { able attempts at texts } \\
\text { on familiar themes that } \\
\text { are not completely } \\
\text { straightforward, } \\
\text { including very simple } \\
\text { narratives. Clauses } \\
\text { are normally linked } \\
\text { using connectors, } \\
\text { such as "and", "then", } \\
\text { "because", "but". }\end{array}$ & $\begin{array}{l}\text { Sentences contain } \\
\text { some longer claus- } \\
\text { es, and signs are } \\
\text { shown of awareness } \\
\text { of basic grammar, } \\
\text { including a range of } \\
\text { tenses. }\end{array}$ & $\begin{array}{l}\text { Vocabulary is made } \\
\text { up of very common } \\
\text { words, but is able } \\
\text { to combine words } \\
\text { and phrases to add } \\
\text { colour and interest } \\
\text { to the message (e.g., } \\
\text { using adjectives). }\end{array}$ & $\begin{array}{l}\text { Clear evidence } \\
\text { of awareness of } \\
\text { some spelling } \\
\text { and punctuation } \\
\text { rules, but mis- } \\
\text { formed words } \\
\text { may occur in } \\
\text { most sentences } \\
\text { in more indepen- } \\
\text { dent texts. }\end{array}$ \\
\hline
\end{tabular}




\begin{tabular}{|c|c|c|c|c|}
\hline A2 & $\begin{array}{l}\text { Can write short } \\
\text { straightforward } \\
\text { coherent texts on } \\
\text { very familiar themes. } \\
\text { A variety of ideas are } \\
\text { presented with some } \\
\text { logical linking. }\end{array}$ & $\begin{array}{l}\text { Is able to make } \\
\text { simple independent } \\
\text { sentences with a } \\
\text { limited number of } \\
\text { underlying struc- } \\
\text { tures. }\end{array}$ & $\begin{array}{l}\text { Vocabulary is made } \\
\text { up of very frequent } \\
\text { words but has } \\
\text { sufficient words } \\
\text { and phrases to get } \\
\text { across the essentials } \\
\text { of the message } \\
\text { aspired to. }\end{array}$ & $\begin{array}{l}\text { Some evidence } \\
\text { of knowledge of } \\
\text { simple punctua- } \\
\text { tion rules, and } \\
\text { the independent } \\
\text { spelling of very } \\
\text { common words. }\end{array}$ \\
\hline $\mathrm{A} 1 / \mathrm{A} 2$ & \multicolumn{2}{|c|}{$\begin{array}{l}\text { Can adapt and build on a few learnt patterns } \\
\text { to make a series of short and simple sen- } \\
\text { tences. This may be a short description or set } \\
\text { of related facts on a very familiar personal } \\
\text { theme. }\end{array}$} & \multicolumn{2}{|c|}{$\begin{array}{l}\text { Can use some words which may resem- } \\
\text { ble L1, but on the whole the message is } \\
\text { recognisable to a reader who does not } \\
\text { know the L1. Spelling may be influenced } \\
\text { by the sound of the word and mother } \\
\text { tongue spelling conventions. }\end{array}$} \\
\hline $\mathrm{A} 1$ & \multicolumn{4}{|c|}{$\begin{array}{l}\text { Can write a small number of very familiar or copied words and phrases and very simple } \\
\text { (pre-learnt) sentence patterns, usually in an easily recognisable way. The spelling often } \\
\text { reflects the sound of the word and mother tongue spelling conventions. }\end{array}$} \\
\hline $\begin{array}{l}\text { Ap- } \\
\text { proach- }\end{array}$ & \multicolumn{4}{|c|}{$\begin{array}{l}\text { Makes an attempt to write some words and phrases, but needs support or a model to } \\
\text { do this correctly. }\end{array}$} \\
\hline
\end{tabular}

\section{Choosing and analysing the assignments}

As stated above, the basis for the detailed analysis is written assignments given at a national French competition for primary school pupils.

Since French is an optional subject, there are no official national exams for primary school pupils. Due to the fact that the number of pupils is relatively small, it is not easy to obtain a relevant corpus of written texts for comparison. The only comparable written tasks available are written texts from the national French competition for primary school pupils.

The national level competition is organised annually for primary school pupils of the final (ninth) year. Competitors are approximately 14 years old, children that Ellis includes in the "11-14" age group and labels with the following expressions: kids, young learners, secondary tweens, teens, early teens, teenagers and juniors (2014, p. 77). In Slovenia, the term secondary school students is not in general use yet, hence these students are instead referred to as final year primary school students.

The national competition is organised on two levels, with individual school competitions serving as qualifiers for the national level. In 2015, there were participants from 35 primary schools, with 147 pupils on the school level and 36 pupils on the national level.

The national competition exam takes 45 minutes and consists of three parts: reading comprehension, five short exercises of various types that are intended to check grammar and vocabulary knowledge, and one writing task. The latter is the focus of the present article. 
For the written assignment, the pupils had to write a guided letter. The instructions were as follows:

You have a new pen pal in France. You are writing to him/her for the first time. Introduce yourself. Describe yourself, tell him/her where you live, speak of your likes and dislikes. Say something about your hobbies. Describe your family. Explain why you are learning French and tell him/ her what you would like to be when you grow up. Important: Introduce yourself with a pseudonym - not with your real name - and write the letter in the traditional letter form.

The instructions were given both in French and Slovenian. According to Pižorn, it would be better to only provide Slovenian instructions, as longer blocks of text written in French, such as instructions and examples, can make the objective grading of linguistic correctness and vocabulary knowledge difficult, since pupils can copy words and structures from the instructions to their own writing (2009, p. 314). On the other hand, it seems sensible to have instructions written in both French and Slovenian despite certain reservations, as children probably feel safer if they are given instructions in the target language as well.

It is perhaps appropriate to explain why pupils are asked to use a pseudonym. All of the competition papers are encoded and graded blind. In the past, it has happened that children used their real names in similar tasks, which resulted in reservations regarding the assessors' fair and objective grading. As stated above, the tasks used in the first part of the exam were classic paper and pencil tasks, like those usually used when testing knowledge on similar occasions, such as the national competition for secondary school students. Despite the mode of testing, authentic texts were used as part of tasks, so it did not only involve checking decontextualised structures. According to Cameron, quoting a study by Rea-Dickins and Rixon (1999): "by far the most often used method of testing was the 'pencil and paper' method, used to check individual parameters of grammar and vocabulary in isolated sentences" (2001, p. 117). The second part of the test paper was a written composition. As proposed by Czura (2013, p. 84), it would make sense to replace classical exam forms with more sensible, authentic and communication-based tasks. Unfortunately, this is not possible due to temporal and logistical limitations, and because of the desire to grade objectively.

When analysing the compositions, the point of departure was the approach of Raaen (2009), who tested pupils aged 7 and 9 attending Norwegian 
primary schools 4 in a longitudinal study. After carrying out an extensive analysis of written compositions, Raaen decided to use the following criteria: length, spelling, subject-verb agreement and usage of progressive verb forms.

After a thorough analysis of content, spelling, vocabulary and linguistic structures, the following criteria were chosen:

- the length of the composition;

- communicative suitability;

- $\quad$ orthography (spelling);

- $\quad$ language proficiency - the suitability of the linguistic structures and vocabulary used.

\section{Length of the composition}

The instructions specify that the written composition is limited to approximately 200 words. If a $10 \%$ deviation is permitted, any composition between 180 and 220 words is defined as acceptable. The analysis shows that 12 compositions were of suitable length, 5 were too long and 19 too short. The shortest composition consisted of only 59 words, while most other compositions that were too short ranged from 130 and 150 words. The longest composition numbered 264 words. Evidence shows that the majority of compositions were essentially shorter, so it is possible that the task was too difficult for the target group. The shorter compositions reflect the problem touched upon above: once pupils had used all of the information from the instructions given, transforming this material into a letter, they ran out of vocabulary items and linguistic structures with which they could expand the letter. They nevertheless tried to fulfil the word count criterion, as it was evident from many of the compositions that the pupils themselves had also counted the number of words.

\section{Communicative suitability}

This criterion involves the suitability of the composition in terms of form (whether it is written as an informal letter) as well as content (whether the author includes all of the required elements).

The content of the letters was mostly suitable. Eleven compositions were missing parts of the required information, typically one and never more than three elements per composition. The most problematic part of the instructions

4 There is an ambition to carry out a similar study in Slovenia, but the coded grading system makes it impossible to follow the individual pupil's progress. Furthermore, due to the small number of pupils learning French, it would be very difficult to receive a comparable corpus of written texts via a different channel. 
was "tell them what you would like to be/do when you grow up", as pupils had generally not mastered the conditional. Further details are given in the interpretation of the analysis.

When assessing the mastering of the use of the traditional letter form, the letters that were accepted as suitable included both an initial and a final salutation written in the informal register and appropriate for a letter to a friend. If it had been a "classical" letter, we would also have insisted on a date and place, but since similar correspondence can take place via e-mail, where there is no need to write the date of the letter, this criterion was omitted.

Ten compositions were inadequate in terms of form: two were written as a formal letter and included the addresses of the sender and recipient, and the other eight lacked the initial and/or final salutation.

As the initial salutation, "Salut" (hello) or "bonjour" (literally: good day) were used most often, but there were a number of cases of Cher/Chère (dear) in conjunction with the recipient's (made up) name.

The letters ended with À bientôt (see you soon), Au revoir (see you), Gros bisous (kisses), Merci de ta réponse (Thanks for your reply), and even the original and authentic Bon, c'est tout, je te laisse. Grosses bises. (free translation: Ok, that is all for now. Sending you kisses).

The endings Je t'aime (I love you), as well as the imperative Réponds! (Reply!) used by pupils were viewed as impolite in the context or were not appropriate for the assignment.

\section{Orthography (spelling)}

Pupils struggled above all with diacritical marks, even with the most basic vocabulary, such as family members. The following spellings appeared: frére/ fréres ${ }^{5}$, even frérés and frerés, mére, pére (correct: frère/s, mère, père). Diacritical signs were also used incorrectly with other frequent words: chere (chère), slovene (slovène), Slovènie, also Slovenié (Slovénie), je suis fortè (je suis forte), trés (très), cinèma (cinéma), secretaire (secrétaire), gèniale (géniale).

In addition to missing or incorrectly used diacritical signs, there were other misspelled words: seur instead of soeur, symphatique or sympatique (sympathique), Jacquline (Jacqueline), je suis excellante (je suis excellente), parc que (parce que).

There were also examples of spelling mistakes that changed the pronunciation or even the meaning: je suis gurmande (je suis gourmande), les gens

5 All of the corpus examples are uncorrected and written in italics. The incorrect examples have not been marked with an asterisk, as that would complicate reading. 
pareseux (paresseux), professiour (professeur), jécute (jécoute), francais (français), la longue française (la langue française).

Providing such mistakes do not compromise the clarity of the message, they are not perceived as crucial at this level of language learning. They are most likely slips rather than mistakes, but it is nevertheless recommended that teachers encourage pupils to pay more attention to precision, so as to avoid similar slips.

There are only two spelling mistakes that seem crucial and could indicate a lack of understanding of linguistic structures: et/est and à/a. Both examples include verbs: the first pair is the conjunction et (and) and the third person of the verb être (to be), while the second pair is the preposition à (on, in) and the third person of the verb avoir (to have). Examples of inappropriate usage found in the corpus are:

il à trois ans (il a)

quel âge à tu (quel âge as-tu)

j'habite a Črnuče (à Črnuče)

il et un peu fou (il est...)

mes chats s'appellent ... est Ginger (et Ginger)

\section{Language proficiency}

After a detailed analysis of the compositions, the problematic structures and vocabulary were arranged into several groups, which are addressed separately in the sections below: incorrect conjugation of basic verbs, incorrect use of gender in articles and adjectives, and noun-adjective agreement, the latter being similar to the category used by Raaen (2010). We have added two additional categories: "elision" (élision - the shortening of an article of a pronoun before a noun or a verb beginning with a vowel) and "mistakes made in complex structures".

\section{Conjugation of verbs}

There are several mistakes found with verb forms, even regarding frequently used verbs that are present in primary school textbooks from Unit 1, such as:

Tu aime? (tu aimes), je n'aimes pas (je n'aime pas), Tu fait? (tu fais), J'a un chat (J'ai), je va (je vais), Qui est tu? (Qui es-tu?), ma mère sais (ma mère sait), je va (je vais), Elles s'appelles (Elles s'appellent), je lit (je lis) 
The examples above are more likely to be slips than "real" - i.e., systemic - mistakes.

Some verbs were left unconjugated:

japprendre français (j’apprends), je faire du sport (je fais), je ne parler bien le français (je ne parle pas bien)

Interestingly enough, there are a large number of mistakes connected to the use of verbs (personal verb endings and infinitives). In certain cases, this might be influenced by the learner's mother tongue: "Rad berem, Lahko govorim s tabo, rad poslušam glasbo." (here the verbs "berem, govorim, poslušam" (English: I read, I speak, I listen) all have first person endings).

j'aime lit (j’aime lire), Je peux parle à toi (je peux parler à toi), je veux joue (je veux jouer), j’aime écoute de la musique (j’aime écouter de la musique), J'aime apprends le français (J'aime apprendre le français), J’adore dance le ballet et joue du piano (J'adore danser ... et jouer), J'apprends le français pour sais beaucoup (pour savoir)

je veux je voyage en France (je veux voyager en France), je veux je suis la proffeseur aussi (je veux être professeur aussi).

There are few verbs in the past tense or in the conditional, and they usually contain mistakes:

j’ai lité (j’ai lu - lité is a non-existing form), j’ai venu (je suis venu - wrong auxiliary verb), je voudrais danse (je voudrais danser), jadore chanté (jadore chanter).

\section{Incorrect use of gender in nouns, noun-adjective agreement}

This is another category where mistakes occur with frequently used words, even with words where the gender is obvious (e.g., sister, brother, father). Regarding noun-adjective agreement, mistakes most often occur because pupils do not know the gender of the noun:

mon soeur (ma), un petit soeur (une petite), ma père (mon père), mon famille (ma)

la chocolat (le), le langue (la), son profession (sa), ton lettre (ta)

le glace (la), le pizza (la)

le lecture (la)

mon animal préférée, (préféré)

les yeux bleu, les yeux bleues (bleus), ma cheveux long (mes cheveux longs), cheveux noir et yeux bleu (noirs/bleus), Il est tres grande (grand), Ses cheveux sont brun et long (bruns et longs), Mes yeux sont bleu et 
grande (bleus et grands), Elle est très sportif (sportive), Il est grande (grand)

dans une petit ville (petite)

\section{Elision - Lélision}

Elision is "the omission of the final vowel before a word starting with a vowel or silent h. Elision in writing is marked with an apostrophe" (Jereb, 2009, p. 14).

This could be classified as an orthographic mistake, even though it is actually caused by the impossibility of pronouncing two vowels together. Recently, it has been observed that this mistake occurs in written compositions rather frequently at all levels of learning, and it would therefore make sense to draw attention to this rule from the beginning of learning. Recognised as a simple mistake, it could be easily identified and avoided if pupils were simply aware of it.

The following variations appeared in the corpus:

je apprends (j’apprends), je aime (j’aime), je étudie (jétudie), je adore (jadore), je achète (jachète), je habite (j’habite)

le alleman (l'allemand)

parce que il fait froid (parce qu'il fait froid)

\section{Mistakes made in more complex structures}

Despite their relatively low language level, some pupils tried to use more complex structures, Not surprisingly, they therefore made mistakes, in most cases connected to the usage of various adjectives and prepositions, such as:

Ma professeur est toujours de bonne humour et jadore elle. (Ma professeur est toujours de bonne humeur et je l'adore), j’adore elle (je l'adore)

J’habite à Trzin, la ville qu'est à côté de Ljubljana (qui est à côté)

J'aime les langues qui jétudie (que jétudie)

J'adore voir les femmes quelles ont des talons (qui ont)

Cette année, je vais à l'Italie (en Italie)

$\grave{A}$ mon temps libre,... (Dans mon temps libre)

Je n'ai pas des frères (de frères), je niai pas de la soeur (pas de soeur), Je viens du Ljubljana, la capitale du Slovénie (de Ljubljana, de Slovenie)

Despite the mistakes, the message conveyed in the sentences is sufficiently clear. 


\section{Vocabulary}

As far as vocabulary is concerned, the pupils resorted to the words provided in the instructions. The vocabulary is basic, as is expected at this level, so there is a lack of variety. There is separate section dedicated to spelling mistakes in the present analysis. Let us offer two examples of vocabulary mistakes:

Je ne sais pas quelle matière je vais faire (quel métier)

J'enseigne français parce que je pense que le français est une belle langue (japprends; confusing the verbs enseigner - to teach and apprendre - to learn).

\section{The influence of Slovenian and English (first foreign language)}

There are certain (rare) cases of mistakes influenced by the mother tongue and - more often, especially in the case of spelling mistakes - by English, which is the first foreign language that most children are taught. As stated by Skela et al.: "Besides the general effects of transfer between two written systems a foreign language learner is also burdened with the phonological system of his or her mother tongue. In oral communication this will be given away by the accent whereas in written communication this can result in some sort of a 'orthographical accent'. For example, English learners whose mother tongue is Dutch tend to duplicate the final consonant ('wekk' instead of 'week'). We can frequently determine the mother tongue of the learner simply by observing their mistakes" (2009, p. 236). It is interesting that the analysis of our corpus reveals a greater influence of the pupils' first foreign language (i.e., English) than their mother tongue.

The influence of the mother tongue is very probable in cases of literal translations:

Quoi est tes loisirs? probably a translation of the informal "What are your hobbies?"

Je veux tous journées avec soleil pour toi, probably: "Želim ti sončne dni” (i.e., I wish you sunny days).

It is interesting that the influence of English could be observed often, especially in spelling, and in some cases English words were even used.

Je suis grande and grosse. (et).

Je déteste la scholl (l'école).

athletic (athlétique), architect (architecte), sympathic (sympathique), colour (couleur), la music (la musique), la dance/je dance (la danse/je danse), les bananas (bananes). 
To conclude the analysis, let us quote a fragment of a unique composition that stands out from the average. Judging by the rich yet prominently informal, colloquial vocabulary, one can assume the author had been in contact with French-speaking people. The composition was written almost phonetically, ignored rules of orthography and posed a considerable challenge to the assessors. If read out loud, the composition appears to be meaningful in content, albeit rather informal in register, but in written form the words are almost unrecognisable.

Je ses pas qua exetelme je veux faire dans ma vie, mes je ses que sa va etre manifique. Se possible je je va etre un milionere, au petetre je va alle dans an pay etranger et je va recountre lamour de ma vie. Je ses pas. Mantniau je va se concetr sur qua se passe mantenau et je va voir qua se pas dans la future.

\section{Summary of the analysis and interpretation of the results}

A total of 36 compositions were analysed, with length, communicative suitability (respecting the form and including all of the required elements) and linguistic competence used as criteria.

Regarding the form, the suitability of the letter length as well as adherence to the criteria of the text type (i.e., whether the letter includes an initial and formal salutation, whether it is written in the proper language register, etc.) were assessed. It was established that only 12 compositions were of proper length (i.e., between 180 and 220 words), while more than $50 \%$ of the compositions were too short. It is possible that the prescribed length could be unsuitable (too long), or that the amount of time available for the written composition could be the issue. Given that the national competition aims to gain insight into the level of knowledge of better pupils, and considering the fact that some compositions were longer than prescribed, one can conclude that the length is appropriate, as it gives better pupils a chance to distinguish themselves.

As far as following instructions is concerned, content analysis reveals that the compositions meet the demands of the task. Eleven compositions lack specific elements from the instructions, in most cases one element per composition. The most problematic part of the instructions was "tell them what you would like to become when you grow up". This part was linguistically challenging: competitors recognised the conditional tense but did not know how to form it, so they either used the present indicative tense or simply ignored this question.

The analysis also covers how the imaginary pen pal was addressed. Most 
participants used an appropriate salutation and a register suitable for a letter written to a friend, while two pupils wrote a formal letter and eight pupils forgot to include the initial or final salutation, or both.

With regard to orthography, there are several mistakes related to the usage of diacritical signs, even in the case of elementary vocabulary such as words for family members. In most cases, the mistakes do not alter the meaning of the word or make comprehension difficult. However, attention needs to be drawn to the pairs à/a and et/est, which are often used incorrectly, although it is impossible to distinguish mistakes from accidental slips. Other examples of language mistakes include many false uses of verb conjugation, use of gender in nouns, and noun-adjective agreement. When conjugating basic verbs, pupils were most likely careless, whereas the frequent incorrect usage of auxiliary verbs and infinitives indicates poor knowledge. Many nouns are used with adjectives of the wrong gender, even with examples as clear as "father", "sister" and "brother". Mistakes related to noun-adjective agreement are often due to pupils not knowing the gender of the specific noun. Such mistakes are relatively frequent in the compositions.

A closer examination of complex structure shows that most mistakes are related to pronouns and prepositions, which is in accordance with the expected level of language skill of pupils of this age. The vocabulary of the shorter compositions consists mainly of the words used in the French instructions, whereas the longer compositions display fairly rich vocabulary. Spelling is occasionally influenced by the mother tongue, as well as by English (the pupils' first foreign language).

Finally, let us point out a relatively frequent mistake that is quite easy to avoid: elision (élision). Teachers should pay more attention to teaching elision in class from the start.

\section{CEFR and AYLLIT descriptors}

The criteria for the assessment of written compositions, as part of the corpus, are expected to contain elements that enable the assessment of compositions according to the instructions given before writing. Hasselgreen and others (2011, p. 21) draw attention to the fact, that "the assessment criteria for writing must reflect the consensus of what good writing is and descriptors based on these criteria must reflect the age and ability of the writers for whom they are being developed".

Since the pupils in question have already succeeded in the first round of the selection process, the curricular standards determined for a second foreign 
language as an elective subject are likely to be surpassed. The national curriculum defines communicative activities for the fulfilment of operative goals and knowledge standards for the $9^{\text {th }}$ year (after three years of foreign language learning), anticipating that "pupils will be able to write a few sentences with the help of a template or sample (e.g., a message to a peer in which they let them know where they are, what they are doing, or where they will meet)" (2013, p. 13). The A1 level according to the CEFR is defined as the minimum standard for this level of learning, whereas the average required standard is not defined. The situation is similar in some other European countries; for example, in France, where pupils leave primary school at the age of 11 . Vanthier (2009, p. 55) states: "In many European countries including France, we consider that at the end of the primary school a pupil should have acquired the level A1 of CEFR. The expected skills in writing are: can write a simple message (e-mail, postcard from holidays), can complete an extremely simple questionnaire. One wonders if the expected level is not undervaluated in some cases, compared to the development capabilities of young learners (...) It might be expected that children leave elementary school with a higher level than A1."

If we compare the CEFR and the AYLLIT descriptors, we find that the CEFR criteria are too general and insufficiently detailed. In order to evaluate the analysed assignments and cover the features that emerge from the analysis, they need to be combined with other descriptors, e.g., descriptors for the general linguistic and vocabulary range.

On the other hand, the AYLLIT criteria seem more appropriate for the description and classification of the analysed assignments, as they are divided into four parts and cover most of the criteria established for analysis: overall structure and range of information, sentence structure and grammatical accuracy, vocabulary and choice of phrase, misformed words and punctuation. There is one "missing" category, namely "following instructions", which includes an evaluation of the length of the written composition and whether or not the pupil has included all of the required information in their composition. The AYLLIT criteria also define the "approaching A1" and "in-between" levels, and are therefore more adapted to our target group. Even if our pupils are between two age groups and cognitively more mature than younger children, their linguistic level can be better described using the AYLLIT criteria, since these criteria are more explicit and adapted to the writing task that was assigned to the pupils. 


\section{Discussion and conclusion}

For the purposes of the present paper, 36 written compositions from the national French competition for pupils of the final year of primary school were analysed. Although the sample is small and statistically not sufficiently relevant, it is still representative if we take into account the number of pupils learning French as a foreign language in Slovenian schools. Several parameters were included in the analysis, those that seemed meaningful in view of the instructions and the language level of the pupils: following instructions, communicative suitability, orthography, grammar and vocabulary. The extra category of "content" was not introduced because guided letters were analysed and pupils had to follow rather rigid instructions.

Prior to the analysis, the hypothesis was accepted that the pupils were capable of writing the required text length and able to write a composition in the form of a letter, including the initial and final salutations. However, it emerged that more than half of the compositions were too short, some significantly so. This could imply that the required number of words was too high and/or that there was not enough time to complete the task, which is useful feedback for the authors of the test. The pupils were able to meet the formal requirements better than the length requirements: there were 10 unsuitable compositions, 2 of which were written as a formal letter while 8 lacked the initial and/or final salutation. The content of the letters was mostly suitable, although certain pupils did omit some information specified in the instructions, most frequently the part that demanded the use of the conditional tense, a structure that was too difficult for the general knowledge of the pupils participating.

The other hypothesis is related to language. Pupils were expected to use basic vocabulary and simple structures without making mistakes that affect comprehension. Even though all of the participants had already succeeded in the school-level competition before entering the national level, the compositions vary greatly regarding language levels. The least successful pupils simply copied the structures given in the instructions, but there were also some relatively elaborate compositions. The areas that appeared to be the most challenging were the conjugation of verbs and noun-adjective agreement. It is surprising that so many mistakes were made with basic verbs: the regular verbs of Group 1 and frequently used irregular verbs (i.e., "être", "avoir", "vouloir") that are present in textbooks from Unit 1. It is also surprising that there were mistakes regarding the gender of some nouns, especially nouns where the gender is obvious, such as "father", "mother", "brother" and "sister". It is impossible to distinguish between real mistakes and lapses made in a moment of inattentiveness, 
or mistakes that arose because time was running out and the pupils could not reread their compositions before handing them in. Some pupils used sentences with fairly complex syntax, but they made certain mistakes, especially with pronouns.

Orthographic mistakes that occur even in common words such as those for family members were, without doubt, unexpected; there were, for example, three different alternative misspellings of the word "frère" (brother). Such issues could be avoided if pupils were more careful. Orthography, in particular, was occasionally influenced by the first foreign language (English).

Teachers could pay much more attention to mistakes related to elision, as they are very frequent in the analysed corpus. This is a mistake that can be avoided simply with greater awareness.

Regarding descriptors that could be used to place the analysed assignments on the CEFR scale, the AYLLIT descriptors, usually used for young learners, seem more appropriate than the more general CEFR descriptors. The AYLLIT descriptors include all of the categories used for the present analysis, except for "following the instructions", which should be added. They are also more detailed and include the "approaching A1" and "in-between" (A1/A2 and $\mathrm{A} 2 / \mathrm{B} 1)$ levels.

The linguistic level of the majority of the pupils participating in the competition seems to be above the minimum level determined by the school curriculum. This is not surprising, as the participants are obviously highly motivated children willing to invest enough effort into learning French to reach the national competition level.

\section{References}

Brumen, M. (2003). Pridobivanje tujega jezika v otroštvu: Priročnik za učitelje; teoretična in praktična izhodišča za učitelje tujega jezika v prvem in drugem triletju osnovne šole. Ljubljana: DZS.

Brumen, M., Čagran, B., \& Rixon, S. (2005). Assessment of Young Learners' Foreign Language in Slovenian Primary Schools. Elope, 2(1-2), 167-184.

Cameron, L. (2001). Teaching Languages to Young Learners. Cambridge: CUP.

Common European Framework of Reference for Languages: Learning, Teaching, Assessment (2001).

Strasbourg: Language Policy Unit. Retrieved 10.08.2015 from http://www.coe.int/t/dg4/linguistic/

Source/Framework_EN.pdf

Copland, F., \& Garton, S. (2014). Key themes and future directions in teaching English to young learners: introduction to the Special Issue. ELT journal, 68(3), 223-230.

Czura, A. (2013). Implementing Portfolio Assessment in Lower Secondary School. Elope, 10(1), 83-94. Dagarin Fojkar, M. (2009). Modeli poučevanja tujega jezika v otroštvu - pregled stanja v Evropi in 
drugje po svetu. In K. Pižorn (Ed.), Učenje in poučevanje dodatnih jezikov v otroštvu (pp. 154-176).

Ljubljana: Zavod Republike Slovenije za šolstvo.

Drew, I., \& Hasselgreen, A. (2008). Young Language Learner (YLL) Research: An Overview of some international and national approaches. Acta Didactica Norge, 2(1), 1-18.

Ellis, G. (2014). 'Young learners': clarifying our terms. ELT journal, 68(1), 75-78.

Gaonac'h, D. (2006). Lapprentissage précoce d'une langue étrangère. Paris: Hachette Éducation. Hasselgreen, A., Kaleidate, V., Maldonado-Martín, N., \& Pižorn, K. (2011). Assessment of young learner literacy linked to the Common European Framework of Reference for Languages. Graz: ECML. Jereb, E. (2009). Francoska slovnica po naše. Ljubljana: Cankarjeva založba.

Enever, J., \& Moon, J. (2010). A global revolution? Teaching English at Primary school. Retrieved 15.08.2015 from https://www.teachingenglish.org.uk/sites/teacheng/files/MoonEnever\%20BC\%2O paper.pdf

Lah Šuster, A. (2013). Učenje tujega jezika v otroštvu - stopnja osebnostne razvitosti in razvitost strategih v 2. triadi OŠ. Vestnik za tuje jezike, V(1-2), 95-113.

Marjanovič Umek, L. (2009). Razvoj otroškega govora: učinek poučevanja in učenja tujega/drugega jezika. In K. Pižorn (Ed.), Učenje in poučevanje dodatnih jezikov v otroštvu (pp. 71-80). Ljubljana: Zavod Republike Slovenije za šolstvo.

Newport, E. L. (1999). Maturational Constraints on Language Learning. Cognitive science, 14, 11-28. Oh, S. (2011). Classroom-based Language Assessment for Young Language Learners. Working Papers in TESOL \& Applied Linguistics, 11(1), 55-56.

Phillips, S. (1993). Young learners. Oxford: OUP.

Pinter, A. (2006). Teaching Young Language Learners. Oxford: OUP.

Pevec Semec, K., Kač, L., Šečerov, N., Lesničar, B., Lipavic Oštir, A., Cajhen, S., \& Strmčnik, L. (2013). Učni načrt: Drugi tuji jezik v 4. do 9. razredu. Neobvezni izbirni predmet. Retrieved 15.06.2015 from http://www.mizs.gov.si/fileadmin/mizs.gov.si/pageuploads/podrocje/os/devetletka/program_ razsirjeni/Drugi_TJ_izbirni_neobvezni.pdf

Pižorn, K. (2009). Raziskave na področju preverjanja/ocenjevanja tujejezikovnega znanja v otroštvu.

In K. Pižorn (Ed.), Učenje in poučevanje dodatnih jezikov v otroštvu (pp. 304-322). Ljubljana: Zavod Republike Slovenije za šolstvo.

Pižorn, K. (2014). The Development of a CEFR-based Scale for assessing Young Foreign Language Learners' Writing Skills. Linguistica, 54, 241-259.

Raaen, G. (2010). A comparison of basic English skills in 7th and 1oth grade. In FoU I Praksis 2009 Rapport fra konferanse om praksisrettet FoU i lloererutdanning. Trondheim: Tapir.

Sešek, U., \& Pižorn, K. (2009). Uporabnost evropkega jezikovnega okvira za mlajše učence. In K. Pižorn (Ed.), Učenje in poučevanje dodatnih jezikov v otroštvu (pp. 290-303). Ljubljana: Zavod Republike Slovenije za šolstvo.

Skela, J., Sešek, U., \& Dagarin Fojkar, M. (2009). Opismenjevanje v drugem/tujem jeziku na zgodnji stopnji. In K. Pižorn (Ed.), Učenje in poučevanje dodatnih jezikov v otroštvu (pp. 290-303). Ljubljana: Zavod Republike Slovenije za šolstvo. 
Sundqvist, P. (2014). Review of 'The Young Language Learning: Research-based Insights into Teaching and Learning' (Hasselgreen, Drew, \& Sørheim, 2012). KAPET, 10(1), 15-23.

Vanthier, H. (2009). L'enseignement aux enfants en classe de langue. Paris: CLE International.

\section{Biographical note}

Meta LAH is an Assistant Professor at the Department of Romance Languages and Literatures, Faculty of Arts, University of Ljubljana. The core area of her research is the methodology of teaching French as a FL (in pre- and in-service teacher training). She is one of the founders of the Slovenian Society of French Teachers and has been the editor of Vestnik za tuje jezike, a journal of foreign languages. A longtime member of the subject testing committee for the General Matura in French, she remains an external examiner.

In 2011, she was awarded the French medal The Knight of National Order of Academic Palms. 